\title{
Prescribing Pattern of Extemporaneous Compounding in Primary Health Care Centers
}

\author{
Indri Hapsari ${ }^{1,2}$, Marchaban $^{3}$, Chairun Wiedyaningsih ${ }^{3} \&$ Susi Ari Kristina ${ }^{3}$ \\ ${ }^{1}$ Doctoral Student, Faculty of Pharmacy Universitas Gadjah Mada Yogyakarta, Indonesia \\ ${ }^{2}$ Faculty of Pharmacy, Universitas Muhammadiyah Purwokerto, Indonesia \\ ${ }^{3}$ Faculty of Pharmacy, Universitas Gadjah Mada Yogyakarta, Indonesia \\ Correspondence: Indri Hapsari, Doctoral Student, Faculty of Pharmacy, Universitas Gadjah Mada, Indonesia; \\ Department of Pharmaceutics and Technology of Pharmacy, Faculty of Pharmacy, Universitas Muhammadiyah \\ Purwokerto, Indonesia. E-mail: indri.h@mail.ugm.ac.id; indrihapsari_ump10@yahoo.co.id
}

Received: September 17, 2018 Accepted: November 5, 2018 Online Published: November 15, 2018

doi:10.5539/gjhs.v10n12p104 URL: https://doi.org/10.5539/gjhs.v10n12p104

\begin{abstract}
Objective: Compounding is one of basic competences and skills should be owned by pharmacists since ages. Shortage of licensed drug supply and patients with special needs had become the major reason for the compounding practice to be performed. Average of drug number given to patients in primary or government health centers in a sheet of prescription compounding was quite high; commonly it included more than one drug given individually or prescribed together. The WHO/INRUD cores drug prescribing indicators were developed to be utilized as a measure of performance in areas related to rational use of medicine in health facilities. This study aimed to analyze prescribing pattern of extemporaneous compounding in primary health care centers.
\end{abstract}

Method: Cross sectional survey method was employed in this study which was conducted at 24 Primary Health Care Centers in Banyumas regency, Central Java Province, Indonesia by collecting data of extemporaneous compounding from the primary health care centers having the compounding percentage $\geq 5 \%$ from total prescription of each. The researchers implemented retrospective data collection which was conducted on 1200 prescription sheets in period of April to June 2017.

Result: The drugs used in extemporaneous compounding were 49 types, and the mostly used were chlorpheniramin maleate (22.54\%), dexamethasone (18.20\%), glycerol guaiacolate (15.36\%), amoxicillin (9.15\%) and paracetamol (7.47\%). Number of drugs used in each extemporaneous compounding was various; one to six drugs per-compounding with its average 2.86 drugs per-prescription of extemporaneous compounding. Generic drugs were mostly used in extemporaneous compounding with percentage $93.88 \%$, while percentage of antibiotic use was low; it was $11.36 \%$. Based on conformity with national formulary in Indonesia, the proper used drug in extemporaneous compounding was $71.43 \%$, while based on conformity with WHO Model List Essential Medicines, it was $46.96 \%$.

Conclusion: In this study, although the drug which was used in dosage form of extemporaneous compounding was still quite high with a range between 1 to 6 drugs in one dosage form, but generally the drug use in form of extemporaneous compounding in primary health care centers was still in accordance with the WHO/INRUD cores drug prescribing indicators that were characterized by high generic drugs and low use of antibiotics in the extemporaneous compounding at the primary health care centers.

Keywords: prescribing pattern, extemporaneous compounding, primary health care centers

\section{Introduction}

Compounding is one of basic competences and skills should be owned by pharmacists since ages. Commonly, changes of chemical dosage form into other forms, from its original form (industrial drug products) were implemented in drug compounding; it was due to request and instruction of compounding personnel based on patients' condition (Giam \& McLachlan, 2008). Dosage form of extemporaneous compounding could be in form of oral and also topical (Kristina, Wiedyaningsih, Widyakusuma, \& Aditama, 2017; Hapsari, Marchaban, Wiedyaningsih, \& Kristina, 2018). Oral dosage can be in form of crushed tablet and capsule content then divided into smaller dosage, or also in form of powders dissolved or suspended into the carrier liquid into an oral liquid 
dosage (Brion, Nunn, \& Rieutord, 2003), while topical dosage form was commonly dermatology in form of semi-solid of unguenta or cream (Thiers, 1998). In some countries, extemporaneous compounding was known as unlicenced, unauthorized, unapproved or unregistered drugs (Giam \& McLachlan, 2008)

Shortage of licensed drug supply and patients with special needs had become the major reason for the compounding practice to be performed. In addition, ease of the drug use, efficiency and also cheaper price were also other reasons why doctors still prescribed extemporaneous compounding to the patients (Pappas, MacPherson, \& Stewart, 2002). The shortage of licenced drugs caused the doctors using unlicenced or off label drugs in extemporaneous compounding; usage of unlicenced or off label drugs for pediatric patients is common in some countries (Giam \& McLachlan, 2008); such as the case in Rotterdam, where the use of unlicenced drugs for pediatric patients was quite high, especially for patients with complex health cases (Conroy et al., 2000). Although extemporaneous compounding is one of traditional compounding, but until now this compounding technique is still used. On the other hands, extemporaneous compounding also remained a concern, because of unwanted cases such as polypharmacy, medication errors, quality of extemporaneous compounding and also the problem of bacterial contamination that may appear in non-sterile dosage form (Allen, 2003).

A study conducted by Widyaswari and Wiedyaningsih (2012) in primary health care centers in Special Region of Yogyakarta showed that dosage forms of extemporaneous compounding mostly prescribed were chlorpeniramine maleate, glycerol guaiacolate, vitamin C, paracetamol, and vitamin B12 (Widyaswari \& Wiedyaningsih, 2012). Another study conducted in University Hospital in Southern Brasil showed the most prescribed unlicenced drugs; the drugs were paracetamol, metoclopramide, dipyrone, ibuprofen and salbutamol (Dos Santos \& Heineck, 2012). While a study conducted in Switzerland Pediatric University Hospital showed the most used unlicenced and off label drugs; the drugs were paracetamol, morphine, cholecalciferol, amoxicillin, mefenamic acid and multivitamins (Di Paolo et al., 2006).

In some countries, many researches of prescribing indicators are refered to the WHO/International Network of Rational Use of Drugs (INRUD) cores drug prescribing indicators (Rehan \& Lal, 2002; Al-Nasser, 1991; Saleh \& Ibrahim, 2006). The WHO/INRUD cores drug prescribing indicators were developed to be utilized as a performance measure in areas related to rational use of medicine at health facilities. These consisted of average number of medicines prescribed per patient encounter, percentage of medicines prescribed by generic name, percentage encounters with an antibiotic prescribed, percentage of encounters with an injection prescribed and percentage of medicines prescribed from an Essential Medicine List (EML) or formulary (World Health Organization [WHO], 1993). A research conducted by Widyaswari and Wiedyaningsih (2012) in primary health care centers in Special Region of Yogyakarta showed that the most prescribed drugs in one dosage form consisted of three types of drugs with average 2.8 drugs per-extemporaneous compounding. The research conducted in Government Health Service Center of India showed average drug use of 2.47, and other study conducted in Government Health Service Center of Saudi Arabia showed average drug use of 2.3 (Widyaswari \& Wiedyaningsih, 2012; Rehan \& Lal, 2002; Al-Nasser, 1991) Average of drug number given to patients in primary or government health centers in a sheet of prescription, both non-extemporaneous compounding and extemporaneous compounding, was quite high; commonly it included more than one drug given individually or prescribed together. In fact, the more drug amount given to the patients, the more occurrences of polypharmacy and would further increase the occurrence of medication error (Koper, Kamenski, Flamm, Bohmdorfer, \& Sonnichsen, 2013). This study aimed to analyze prescribing pattern of extemporaneous compounding in the primary health care centers

\section{Methods}

\subsection{Study Design}

This was an observational study using cross sectional descriptive survey method conducted at Primary Health Care Centers in Banyumas Regency, Central Java Province, Indonesia; the period of the research was 3 months (April to June 2017). It included two parts of survey. The researchers used retrospective data collected from April to June 2017 at Primary Health Care Centers in the regency. The prior survey observed percentage of extemporaneous compounding prescription at the public health care centers. The centers would not be involved in the next survey if the percentage felt under $5 \%$. The next survey data explored the compounding prescription at the public health care centers. The further survey was conducted by the researchers using observation to identify the sampled extemporaneous compounding prescription. 


\subsection{Sample Criteria}

The researchers set all extemporaneous compounding found in 28 Primary Health Care Centers in Banyumas Regency, Central Java, Indonesia as the population in this study.

\subsubsection{Inclusion Criteria}

All extemporaneous compounding prescriptions taken from Primary Health Care Centers in Banyumas Regency, Central Java with a percentage of extemporaneous compounding $\geq 5 \%$ prescribed by doctors, midwives and nurses intended for adult and pediatric patients were set as the inclusion criteria based on the prior survey. The data of prior survey were used to select Primary Health Care Centers as its sample based on criteria of extemporaneous compounding in the Primary Health Care Center $\geq 5 \%$.

\subsubsection{Exclusion Criteria}

Prescriptions without any extemporaneous compounding were set as its exclusion criteria. The researchers excluded Primary Health Care Center with its extemporaneous compounding less than $5 \%$ of the total prescriptions in this study. Based on the results of a survey of prescriptions at 28 health centers, there are four Primary Health Care Centers with less than 5\% extemporaneous compounding of total prescriptions. Therefore, the four centers are not included in the sampling, so that there are only 24 samples in this study.

Total number of extemporaneous compounding selected is 1200 from 24 primary health care centers. Prescription sampling from each primary health care center is conducted by randomly stratified the data on the number of extemporaneous compounding from survey results of the compounding that have been executed previously.

\subsection{Ethical Considerations}

The ethical approval of this study was issued by the Ethics Commission of Medical Faculty, Universitas Jendral Soedirman with No.: 2294/UN23.07.5.1/PN.1/2017

\subsection{Data Collection and Analysis}

The researchers collected research data in stages by collecting prescription samples from the primary health care centers located closest to the researchers to the most remote ones. They involved trained surveyor pharmacists in each sampling at each primary health care center. The data collection was coordinated by the researchers, where in each sampling they participated in the sampling to control and supervise them. The obtained data are written in data collection sheets and then the data are analyzed descriptively and compared with the WHO/INRUD cores drug prescribing indicators for evaluating medicines usages pattern as a measure of performance to rational use of medicine in primary health care centers. The prescribing indicator used in the study consist of average number of medicines prescribed per patient encounter, percentage of medicines prescribed by generic name, percentage encounters with an antibiotic prescribed, percentage of medicines prescribed from an Essential Medicine List (EML) World Health Organization (WHO) and percentage of medicines percribed from an national formulary in Indonesia. Percentage of encounters with an injection prescribed was not analyzed because prescription of extemporaneous compounding used as non-sterile extemporaneous compounding, therefore the injection was not used in non-sterile extemporaneous compounding.

\section{Result}

Based on the identification result toward 1200 prescription of extemperanous compounding, there were 49 drugs used in extemporaneous compounding in primary health care centers in Banyumas Regency, Central Java. The most drugs used in extemporaneous compounding in the primary health care centers were chlorpheniramin maleate $(22.54 \%)$, dexamethasone (18.20\%), glycerol guaiacolate $(15.36 \%)$, amoxicillin $(9.15 \%)$ and paracetamol (7.47\%). (Table 1)

The research showed that obtained result between the most prescribed drugs and the drug group had correlation; where the most prescribed drugs would also impact to the prescribed drug group. Based on the result, from the most three prescribed drugs, chlorpheniramin maleate was included into antihistamin group (23.80\%), dexamethasone was included into corticosteroids group (21.41\%), and glycerol guaiacolate was included into expectorant group (17.07\%). (Figure 1) 
Table 1. Drugs used in extemporaneous compounding dosage in Primary Health Centers

\begin{tabular}{|c|c|c|c|c|}
\hline No. & Drugs & Dosage form & Number & Percentage (\%) \\
\hline 1. & Chlorpheniramine maleat & Tablet $4 \mathrm{mg}$ & 857 & 22.54 \\
\hline 2. & Dexamethasone & Tablet $0.5 \mathrm{mg}$ & 692 & 18.20 \\
\hline 3. & Glyseril guaikolat & Tablet $100 \mathrm{mg}$ & 584 & 15.36 \\
\hline \multirow{2}{*}{4.} & \multirow{2}{*}{ Amoxicillin } & Tablet $500 \mathrm{mg}$ & 270 & \multirow{2}{*}{9.15} \\
\hline & & Suspension $125 \mathrm{mg} / \mathrm{ml}$ & 78 & \\
\hline \multirow{2}{*}{5.} & \multirow{2}{*}{ Paracetamol } & Tablet $500 \mathrm{mg}$ & 282 & \multirow{2}{*}{7.47} \\
\hline & & Syrup $120 \mathrm{mg} / 5 \mathrm{ml}$ & 2 & \\
\hline 6. & Acid ascorbic & Tablet $50 \mathrm{mg}$ & 281 & 7.39 \\
\hline 7. & Vitamin B Complex & Tablet & 127 & 3.34 \\
\hline 8. & Salbutamol & Tablet $4 \mathrm{mg}$ & 112 & 2.94 \\
\hline \multirow{2}{*}{9.} & \multirow{2}{*}{ Ambroxol } & Tablet $30 \mathrm{mg}$ & 49 & \multirow{2}{*}{1.47} \\
\hline & & Syrup $15 \mathrm{mg} / \mathrm{ml}$ & 7 & \\
\hline 10. & Prednisolone & Tablet $5 \mathrm{mg}$ & 49 & 1.30 \\
\hline 11. & Cetirizin & Tablet $10 \mathrm{mg}$ & 48 & 1.26 \\
\hline 12. & Pyridoxine (Vitamin B6) & Tablet $10 \mathrm{mg}$ & 42 & 1.11 \\
\hline 13. & Calsium laktat & Tablet $500 \mathrm{mg}$ & 34 & 0.90 \\
\hline 14. & $\begin{array}{l}\text { Molexflu (Paracetamol, Phenylpropalonamine } \\
\mathrm{HCl} \text {, Chlorpheniramine maleat) }\end{array}$ & Tablet & 30 & 0.80 \\
\hline 15. & Metil Prednisolon & Tablet 4mg, $8 \mathrm{mg}$ & 29 & 0.76 \\
\hline 16. & Hydrocortisone & Cream or oinment $1 \%, 2.5 \%$ & 26 & 0.68 \\
\hline 17. & Gentamycin & Cream or ointment $0.1 \%$ & 23 & 0.60 \\
\hline 18. & Betamethasone & Cream $1 \%$ & 18 & 0.47 \\
\hline \multirow{2}{*}{19.} & \multirow{2}{*}{ Cefadroxil } & Tablet $500 \mathrm{mg}$ & 12 & \multirow{2}{*}{0.42} \\
\hline & & Suspension $125 \mathrm{mg} / 5 \mathrm{ml}$ & 4 & \\
\hline 20. & Domperidon & Tablet $10 \mathrm{mg}$ & 15 & 0.40 \\
\hline \multirow{2}{*}{21.} & \multirow{2}{*}{ Ibuprofen } & Tablet $200 \mathrm{mg}$ & 14 & \multirow{2}{*}{0.40} \\
\hline & & Suspension $100 \mathrm{mg} / 5 \mathrm{ml}$ & 1 & \\
\hline \multirow{2}{*}{22.} & \multirow{2}{*}{ Antasida } & Tablet $500 \mathrm{mg}$ & 13 & \multirow{2}{*}{0.37} \\
\hline & & Suspension $200 \mathrm{mg} / 5 \mathrm{ml}$ & 1 & \\
\hline 23. & Asam mefenamat & Tablet $500 \mathrm{mg}$ & 9 & 0.24 \\
\hline 24. & Oxytetracyclin & Cream or ointment $3 \%$ & 9 & 0.24 \\
\hline 25. & Thiamine (Vitamin B1) & Tablet25 mg & 8 & 0.21 \\
\hline 26. & N- Asetilsistein & Capsul $200 \mathrm{mg}$ & 6 & 0.16 \\
\hline 27. & Miconazole & Cream $2 \%$ & 6 & 0.16 \\
\hline 28. & Cyanocobalamine (Vitamin B12) & Tablet $50 \mathrm{mcg}$ & 6 & 0.16 \\
\hline \multirow{2}{*}{29.} & \multirow{2}{*}{ Acyclovir } & Tablet $400 \mathrm{mg}$ & 4 & \multirow{2}{*}{0.13} \\
\hline & & Cream $5 \%$ & 1 & \\
\hline 30. & Metronidazole & Tablet $500 \mathrm{mg}$ & 5 & 0.13 \\
\hline 31. & (sulfamethoxazole & Tablet $480 \mathrm{mg}$ & 5 & 0.13 \\
\hline
\end{tabular}




\begin{tabular}{|c|c|c|c|c|}
\hline 32. & Ketoconazole & Cream $2 \%$ & 5 & 0.13 \\
\hline 33. & Ephedrin & Tablet $12.5 \mathrm{mg}$ & 5 & 0.13 \\
\hline 34. & Thiamphenicol & Tablet $500 \mathrm{mg}$ & 4 & 0.10 \\
\hline 35. & Ranitidin & Tablet $150 \mathrm{mg}$ & 4 & 0.10 \\
\hline \multirow{2}{*}{36.} & \multirow{2}{*}{ Eritromycin } & Tablet $500 \mathrm{mg}$ & 1 & \multirow{2}{*}{0.10} \\
\hline & & Suspension $200 \mathrm{mg} / 5 \mathrm{ml}$ & 3 & \\
\hline 37. & Cefixime & Tablet $100 \mathrm{mg}, 200 \mathrm{mg}$ & 3 & 0.07 \\
\hline 38. & Zink & Tablet $20 \mathrm{mg}$ & 3 & 0.07 \\
\hline \multirow{2}{*}{39.} & \multirow{2}{*}{ Chloramphenicol } & Capsul 250 mg & 2 & \multirow{2}{*}{0.07} \\
\hline & & Syrup $125 \mathrm{mg} / 5 \mathrm{ml}$ & 1 & \\
\hline 40. & Albendazole & Tablet $400 \mathrm{mg}$ & 2 & 0.05 \\
\hline 41. & Obat Batuk Hitam & Solutio $100 \mathrm{ml}$ & 2 & 0.05 \\
\hline 42. & Papaverin & Tablet $10 \mathrm{mg}$ & 1 & 0.03 \\
\hline 43. & Aminophilin & Tablet $200 \mathrm{mg}$ & 1 & 0.03 \\
\hline 44. & Diazepam & Tablet5 mg & 1 & 0.03 \\
\hline 45. & Bromheksin & Tablet $4 \mathrm{mg}$ & 1 & 0.03 \\
\hline 46. & Clindamycin & Cream $1 \%$ & 1 & 0.03 \\
\hline 47. & Scabimide (Permethrin) & Cream $5 \%$ & 1 & 0.03 \\
\hline 48. & Captopril & Tablet $25 \mathrm{mg}$ & 1 & 0.03 \\
\hline 49. & Dimenhidrinat & Tablet $50 \mathrm{mg}$ & 1 & 0.03 \\
\hline Total & & & 3802 & 100 \\
\hline
\end{tabular}

The dosage form which was made based on instruction of prescription writer in primary health care centers in Banyumas regency, Central Java were in three dosage forms namely puyer (crushed tablet), suspension and oinment/cream. Puyer consisted of 1 to 6 drugs, suspension consisted of 2 to $5 \mathrm{drugs}$, and ointment/cream consisted of 2 to 3 drugs. Figure 2 showed drug numbers that were mostly available in one compounding dosage; it was 3 drugs (46.05\%) with average number of drug use per-compounding dosage forms were 2.89 (Table 3 ).

Based on conformity with national formulary in Indonesia, the drugs used in extemporaneous compounding dosage made in the primary health care centers had met conformity percentage of $71.43 \%$, while based on WHO Model List of Essential Medicine (EML), the drugs used in extemporaneous compounding that had met the conformity was $46.96 \%$ (Table 3 ). Table 3 also showed that generic drugs $(93.88 \%)$ were used in extemporaneous compounding at the primary health care centers, and antibiotic use was $11.36 \%$. 
Five most commonly extemporaneous compounding prescribed based on group of drugs $(n=3802)$

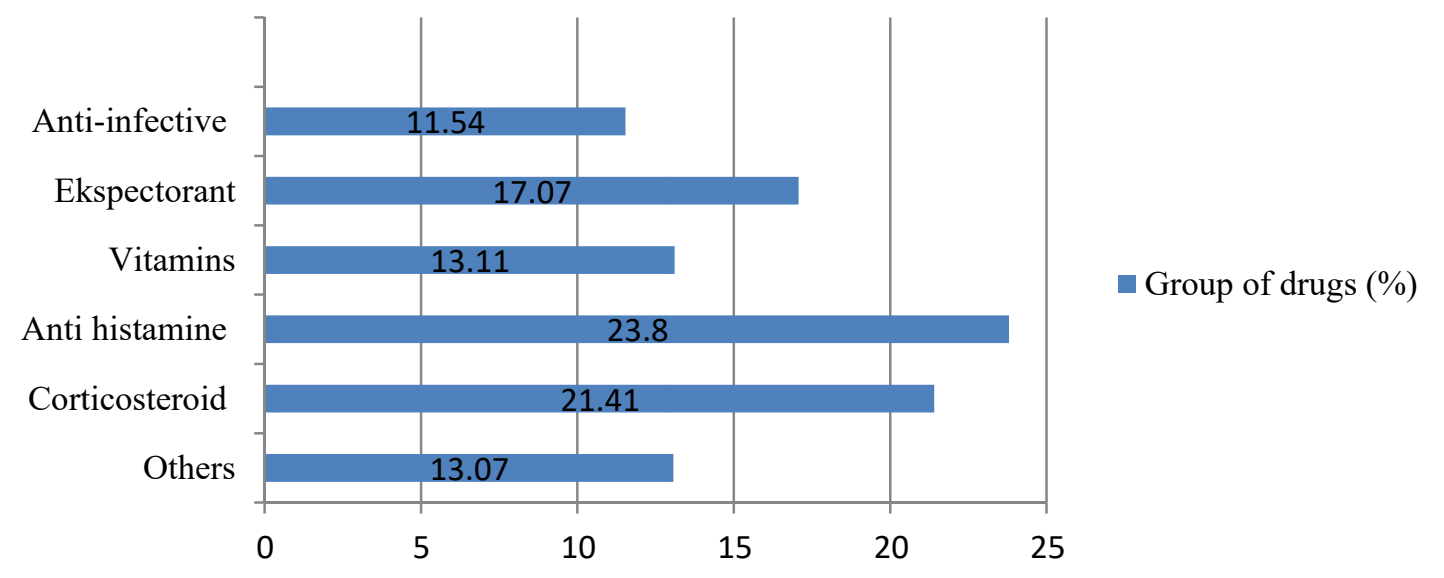

Figure 1. Five most commonly extemporaneous compounding prescribed based on group of drugs

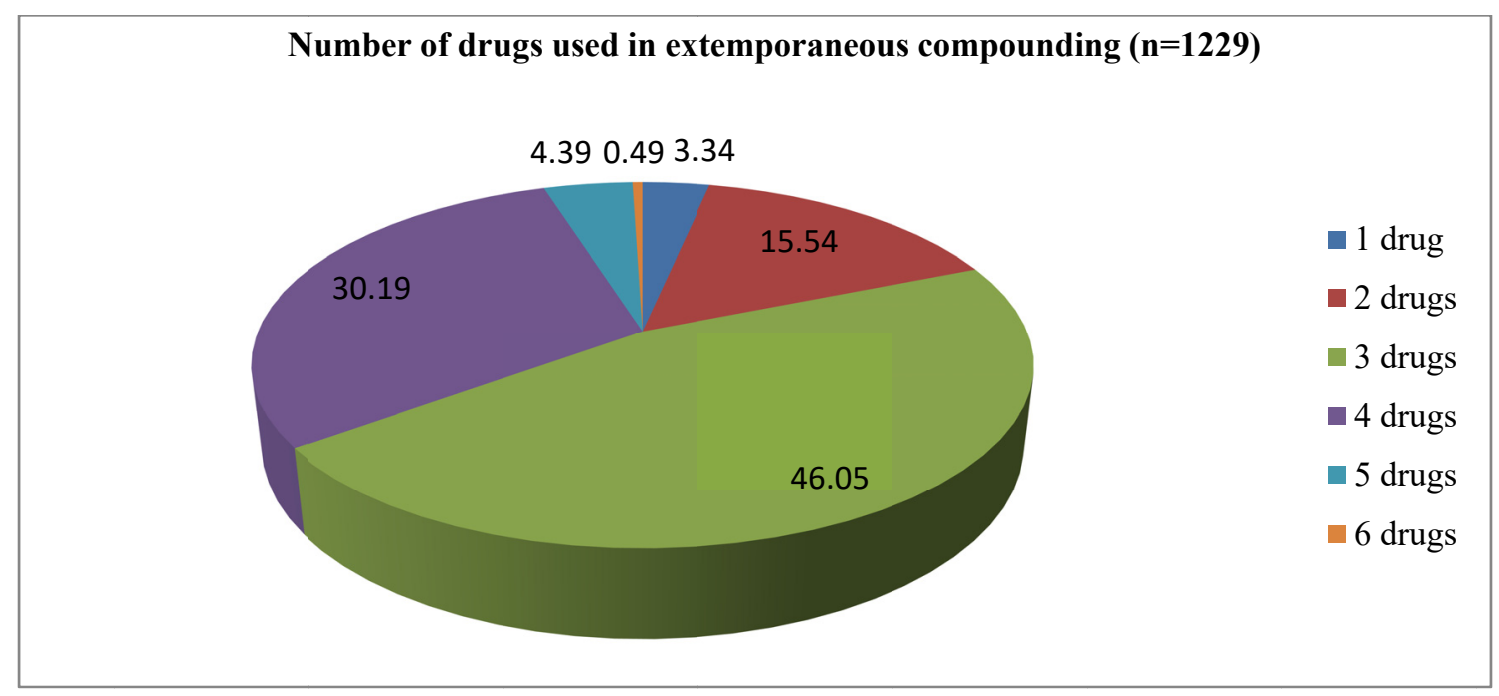

Figure 2. Number of drugs used in extemporaneous compounding 
Table 2. Check list conformity of drugs used in extemporaneous compounding with the National Formulary in Indonesia and WHO Model List of Essential Medicines

\begin{tabular}{|c|c|c|c|c|}
\hline \multirow[b]{2}{*}{ No. } & \multirow[b]{2}{*}{ Drugs } & \multirow[b]{2}{*}{ Dosage form } & National Formulary in & WHO Model List \\
\hline & & & $\begin{array}{l}\text { Indonesia (Health } \\
\text { Facility-Level I) }\end{array}$ & $\begin{array}{l}\text { of Essential } \\
\text { Medicines }\end{array}$ \\
\hline 1. & Chlorpheniramine maleat & Tablet $4 \mathrm{mg}$ & - & - \\
\hline 2. & Dexamethasone & Tablet $0.5 \mathrm{mg}$ & $\sqrt{ }$ & $\sqrt{ }$ \\
\hline 3. & Glyseril guaikolat & Tablet $100 \mathrm{mg}$ & - & - \\
\hline 4. & Amoxicillin & $\begin{array}{l}\text { Tablet } 500 \mathrm{mg} \\
\text { Suspension } 125 \mathrm{mg} / \mathrm{ml}\end{array}$ & $\sqrt{ }$ & $\sqrt{ }$ \\
\hline 5. & Paracetamol & $\begin{array}{l}\text { Tablet } 500 \mathrm{mg} \\
\text { Syrup } 120 \mathrm{mg} / 5 \mathrm{ml}\end{array}$ & $\sqrt{ }$ & $\sqrt{ }$ \\
\hline 6. & Acid ascorbic & Tablet $50 \mathrm{mg}$ & $\sqrt{ }$ & $\sqrt{ }$ \\
\hline 7. & Vitamin B Complex & Tablet & $\sqrt{ }$ & - \\
\hline 8. & Salbutamol & Tablet $4 \mathrm{mg}$ & $\sqrt{ }$ & $\sqrt{ }$ \\
\hline 9. & Ambroxol & $\begin{array}{l}\text { Tablet } 30 \mathrm{mg} \\
\text { Syrup } 15 \mathrm{mg} / \mathrm{ml}\end{array}$ & - & - \\
\hline 10. & Prednisolone & Tablet $5 \mathrm{mg}$ & $\sqrt{ }$ & $\sqrt{ }$ \\
\hline 11. & Cetirizin & Tablet $10 \mathrm{mg}$ & - & - \\
\hline 12. & Pyridoxine (Vitamin B6) & Tablet $10 \mathrm{mg}$ & $\sqrt{ }$ & $\sqrt{ }$ \\
\hline 13. & Calsium laktat (Kalk) & Tablet $500 \mathrm{mg}$ & $\sqrt{ }$ & $\sqrt{ }$ \\
\hline 14. & $\begin{array}{l}\text { Molexflu (Paracetamol, } \\
\text { Phenylpropalonamine } \mathrm{HCl} \text {, } \\
\text { Chlorpheniramine maleat) }\end{array}$ & Tablet & - & - \\
\hline 15. & Metil Prednisolon & Tablet 4mg, $8 \mathrm{mg}$ & - & - \\
\hline 16. & Hydrocortisone & Cream or oinment $1 \%, 2.5 \%$ & $\sqrt{ }$ & $\sqrt{ }$ \\
\hline 17. & Gentamycin (salep mata, inj) & Cream or ointment $0.1 \%$ & - & - \\
\hline 18. & Betamethasone & Cream $0.1 \%$ & $\sqrt{ }$ & $\sqrt{ }$ \\
\hline 19. & Cefadroxil & $\begin{array}{l}\text { Tablet/kapsul } 500 \mathrm{mg} \\
\text { Suspension } 125 \mathrm{mg} / 5 \mathrm{ml}\end{array}$ & $\sqrt{ }$ & - \\
\hline 20. & Domperidon & Tablet $10 \mathrm{mg}$ & $\sqrt{ }$ & - \\
\hline 21. & Ibuprofen & $\begin{array}{l}\text { Tablet } 200 \mathrm{mg} \\
\text { Suspension } 100 \mathrm{mg} / 5 \mathrm{ml}\end{array}$ & $\sqrt{ }$ & $\sqrt{ }$ \\
\hline 22. & Antasida & $\begin{array}{l}\text { Tablet } 500 \mathrm{mg} \\
\text { Suspension } 200 \mathrm{mg} / 5 \mathrm{ml}\end{array}$ & $\sqrt{ }$ & - \\
\hline 23. & Asam mefenamat & Tablet/kapsul 500 mg & $\sqrt{ }$ & - \\
\hline 24. & Oxytetracyclin (inj) & Cream or ointment $3 \%$ & - & - \\
\hline 25. & Thiamine (Vitamin B1) & Tablet $25 \mathrm{mg}$ & $\sqrt{ }$ & - \\
\hline 26. & N-Asetilsistein & Capsul 200 mg & $\sqrt{ }$ & - \\
\hline 27. & Miconazole & Cream $2 \%$ & $\sqrt{ }$ & $\sqrt{ }$ \\
\hline 28. & Cyanocobalamine (Vitamin B12) & Tablet $50 \mathrm{mcg}$ & $\sqrt{ }$ & - \\
\hline 29. & Acyclovir & $\begin{array}{l}\text { Tablet } 400 \mathrm{mg} \\
\text { Cream } 5 \%\end{array}$ & $\sqrt{ }$ & $\sqrt{ }$ \\
\hline
\end{tabular}




\begin{tabular}{|c|c|c|c|c|}
\hline 30. & Metronidazole & Tablet $500 \mathrm{mg}$ & $\sqrt{ }$ & $\sqrt{ }$ \\
\hline 31. & $\begin{array}{l}\text { Cotrimoxazole (sulfamethoxazole } \\
+ \text { trimethoprim) }\end{array}$ & Tablet $480 \mathrm{mg}$ & $\sqrt{ }$ & $\sqrt{ }$ \\
\hline 32. & Ketoconazole & Cream $2 \%$ & $\sqrt{ }$ & - \\
\hline 33. & Ephedrin (inj) & Tablet $12.5 \mathrm{mg}$ & - & - \\
\hline 34. & Thiamphenicol & Tablet $500 \mathrm{mg}$ & - & - \\
\hline 35. & Ranitidin & Tablet $150 \mathrm{mg}$ & $\sqrt{ }$ & $\sqrt{ }$ \\
\hline 36. & Eritromycin & $\begin{array}{l}\text { Tablet } 500 \mathrm{mg} \\
\text { Dry sirup } 200 \mathrm{mg} / 5 \mathrm{ml}\end{array}$ & $\sqrt{ }$ & $\sqrt{ }$ \\
\hline 37. & Cefixime & Tablet $100 \mathrm{mg}, 200 \mathrm{mg}$ & $\sqrt{ }$ & $\sqrt{ }$ \\
\hline 38. & Zink & Tablet $20 \mathrm{mg}$ & $\sqrt{ }$ & $\sqrt{ }$ \\
\hline 39. & Chloramphenicol & $\begin{array}{l}\text { Capsul } 250 \mathrm{mg} \\
\text { Suspensi } 125 \mathrm{mg} / 5 \mathrm{ml}\end{array}$ & $\sqrt{ }$ & $\sqrt{ }$ \\
\hline 40. & Albendazole & Tablet $400 \mathrm{mg}$ & $\sqrt{ }$ & $\sqrt{ }$ \\
\hline 41. & Obat Batuk Hitam & Solutio $100 \mathrm{ml}$ & - & - \\
\hline 42. & Papaverin & Tablet $10 \mathrm{mg}$ & - & - \\
\hline 43. & Aminophilin & Tablet $200 \mathrm{mg}$ & $\sqrt{ }$ & - \\
\hline 44. & Diazepam & Tablet $5 \mathrm{mg}$ & $\sqrt{ }$ & $\sqrt{ }$ \\
\hline 45. & Bromheksin & Tablet $4 \mathrm{mg}$ & - & - \\
\hline 46. & Clindamycin (kaps/tab)inj & Cream $1 \%$ & - & - \\
\hline 47. & Scabimide (Permethrin) & Cream $5 \%$ & $\sqrt{ }$ & $\sqrt{ }$ \\
\hline 48. & Captopril & Tablet $25 \mathrm{mg}$ & $\sqrt{ }$ & - \\
\hline 49. & Dimenhidrinat & Tablet $50 \mathrm{mg}$ & $\sqrt{ }$ & - \\
\hline Total & & & 35 & 23 \\
\hline
\end{tabular}

Table 3. The use of drugs in extemporaneous compounding in Primary Health Care Centers based on WHO/INRUD cores drug prescribing indicators

\begin{tabular}{lll}
\hline No. & Indicators & Value \\
\hline 1. & Average number of medicines prescribed per patient encounter & 2.86 \\
2. & Percentage of medicines prescribed by generic name & $93.88 \%$ \\
3. & Percentage encounters with an antibiotic prescribed & $11.36 \%$ \\
4. & Percentage of medicines percribed from an Essential Medicine List (EML) & $46.96 \%$ \\
5. & Percentage of medicines percribed from an national formulary & $71.43 \%$ \\
\hline
\end{tabular}

\section{Discussion}

Based on the identification result of extemporaneous compounding in the primary health care centers, it consisted of 1 to 6 drugs with the highest percentage from 3 drugs $(46.05 \%)$ with the average 2.86 drugs per-prescription, the result was in line with the study conducted by Widyasari and Wiedyaningsih (2012) in Special Region of Yogyakarta; it showed 3 drugs in one compounding dosage in common with average 2.8 drugs per-compounding prescription(Widyaswari \& Wiedyaningsih, 2012). Comparing to the standard of WHO, the average of extemporaneous compounding was still high because the standard was 1.6-1.8 (World Health Organization [WHO], 1993). The number of prescribed drugs in a prescription sheet per-patient made in primary health care centers in some countries such as India was 2.47 and Saudi Arabia was 2.30; it was almost the same with Indonesia; 2 to 3 drugs in a extemporaneous compounding. The drug numbers in the countries were higher compared to the average drugs ( 1 to 2 per-prescriptions) in the following countries: Spain (1.31), French (1.50) and Italia (1.46) 
(O'Brien, 1984). The average drug number given in Indonesia was quite high compared to other countries, it could cause polypharmacy and increase medication error cases (Koper et al., 2013). In addition, extemporaneous compounding drugs (unlicenced drugs) given to pediatric patients often correlated to adverse drug reaction cases, it because the available licenced drugs usually were not formulated for pediatric patients, so conformation on dose, dosage form, and procedure were required for the patients (Wiedyaningsih, Hakimi, Soenarto, \& Suryawat, 2016).

The mostly prescribed drugs in primary health care centers in Banyumas regency were chlorpheniramine maleate, dexamethasone, glycerol guaiacolate, amoxicillin and paracetamol. These results were similar to prescribing patterns conducted by Widyasari \& Wiedyaningsih in primary health care centers in Special Region of Yogyakarta (2012); it found that the mostly prescribed drugs were chlorpheniramine maleate, glycerol guaiacolate, vitamin C, and paracetamol, but the antibiotic use in primary health care centers in Yogyakarta was relatively lower (Widyaswari \& Wiedyaningsih, 2012). Comparing to extemporaneous compounding done in some countries such as Netherland and Switzerland; there was similar drugs that were mostly prescribed paracetamol dan amoxicillin, while in Brasil, the mostly prescribed drug was paracetamol (Dos Santos \& Heineck, 2012; Di Paolo et al., 2006; 't Jong et al., 2002)

Viewed from mostly prescribed drug groups, there were groups of antihistamine, antiinfektive, expectorant, corticosteroid and vitamins. The drug group used in extemporaneous compounding in centers in Banyumas regency, Central Java were almost the same with the drug group prescribed in primary health care centers in Saudi Arabia; the groups were analgetics, antipyretics, vitamin and cough medications. It because most patients in the country were diagnosed Upper Respiratory Tract Infection (Al-Nasser, 1991).

The antibiotic use in the primary health care centers was $11.36 \%$. Comparing to standard of WHO, the prescription of antibiotic for countries which prevalent with infection cases was in between 15-20\% (World Health Organization [WHO], 1993), so antibiotic use in the primary health care centers was low. It decreased significantly comparing to the antibiotic use in Indonesia a few years ago; it was 43.0\% in 1993 (World Health Organization [WHO], 1996). The low use of antibiotic also happened in primary health care centers in Malaysia (23.2\%) (Saleh \& Ibrahim, 2006)]. The countries with high antibiotic use were Bahrain (45.8\%) (Otoom, Culligan, Al-Assoomi, \& Al-Ansari, 2010) and also Kamboja (66\%) (Chareonkul, Khun, \& Boonshuyar, 2002). One of the reasons why antibiotic used in high dose was because of doctors and patients' willingness to recover more quickly from illnesses, but it actually reffered to the symptoms only, not the diagnosis (Saleh \& Ibrahim, 2006). The antibiotic use with high dose could cause antibiotic resistence; this not only affected the severity of patients' clinical condition, but also had an economic impact which will cost more because the deseases were possibly getting worse or even not healed at all.

The drug use in the primary health care centers in Banyumas regency, Central Java were mostly in form of generic drugs (93.88\%); 3 of 49 prescribed drugs were not generic (two oral dosage namely Molexflu, Obat Batuk Hitam ) and one more topical dosage namely Scabimite. A high percentage of generic drugs usage in primary health care centers indicated that they had followed Health Ministerial Regulation in 2010 about the obligation of prescribing generic drugs by doctors at government health service facilities. It also because the primary health cares centers were in the first level of government health service facility as the gate keeper in health services in Indonesia. In addition, with the limited budget, so that drugs used in the primary health care centers were mostly in form of qualified generic drugs with a cheap price and affordable to the community.

Based on the drug use conformity in extemporaneous compounding done in primary health care centers in Banyumas regency-Central Java with the national formulary of Indonesia for the first level of health service facility (Kementerian Kesehatan Republik Indonesia [Kemenkes RI], 2017), it met the percentage of conformity of $71.43 \% ; 35$ of 49 drugs used in extemporaneous compounding had been appropriate with the national formulary in Indonesia. The existence of $28.57 \%$ incompatibility between the drugs used in prescription with the national formulary because there was a policy from the regional health office where the drugs used or prescribed by each primary health center refered to the Formulary Drug of Basic Health Care (FOPKD) in the primary health care centers made and issued by the regional health office in each region. The FOPKD in each primary health care center refered to the national formulary, consequently most drugs on FOPKD were also available on the national formulary, although some drugs were not same because they should be conformed to condition of each primary health care center or the region (Departemen Kesehatan Republik Indonesia [Depkes RI], 2007). While based on drug list of WHO Model List Essential Medicines 2017, drug conformity which was used was 46,96\% (World Health Organization [WHO], 2011). It because there were some drugs in the list that were not same in dosage form used in extemporaneous compounding such as clindamycin which was available in form of cream, but in WHO Model List Essential Medicines 2017 it was in form of tablet/capsule and injection. It was possible because 
prescription of extemporaneous compounding used as the research sample was non-sterile extemporaneous compounding both in form of oral and topical dosages, so the injection dosage was not used in non-sterile extemporaneous compounding.

Existence of most similiarity between Indonesian national formulary and WHO Model List Essential Medicines was because it is functioned as reference source in arranging the national formulary, although there were some drugs did not exist in WHO Model List Essential Medicines, because the national formulary was the list of selected drugs needed and should be available in health service facilities in implementing National Health Insurance, so it was adjusted with the needs of Indonesian community. In addition, there are several criteria used, such as having good efficacy and safety based on current and valid scientific evidence, having benefit-risk that was most beneficial for patients, having authorized licenses approved by BPOM (Indonesian National Agency of Drug and Food Control) and having a cost beneficial ratio (Kementerian Kesehatan Republik Indonesia [Kemenkes RI], 2016). Overall, viewed from the drugs used in extemporaneous compounding, mostly they were not in accordance yet with WHO Model List Essential Medicines 2017; there were only 23 appropriate drugs. It showed the essential drugs that should be available in primary health care centers were relatively still limited. In fact, patients had their own right to use essential drugs available in health care facilities. Inappropriateness in health treatment and prescribing in primary health care centers could have a wide impact on health services for community, because they were the main gateway in providing health services in the community.

The researchers were able to obtain 1200 samples of prescriptions in 24 Primary Health Care Centers although the study was conducted only in a regency located in Central Java, Indonesia; generally, it is expected to describe prescribing pattern of extemporaneous compounding done in Primary Health Care Centers in Indonesia. The research limitation was that the researchers did not collect the samples in other community pharmacy including drugstores (pharmacies), clinics, and hospitals.

\section{Conclusion}

In this study, although the drug which was used in dosage form of extemporaneous compounding was still quite high with a range between 1 to 6 drugs in one dosage form, but generally the drug use in form of extemporaneous compounding in primary health care centers was still in accordance with the WHO/INRUD cores drug prescribing indicators that were characterized by high generic drugs and low use of antibiotics in the extemporaneous compounding at the primary health care centers.

\section{Acknowledgements}

The researchers are very grateful to Indonesian Lecturer Scholarship of Domestic Affairs (BUDI-DN), a collaboration between the Ministry of Research, Technology and Higher Education and Endowment Fund for Education of Indonesia (LPDP), which has supported this research financially. We would like to present our thanks to the Head of Regional Health Office and Heads of Public Health Centers in Banyumas Regency, Central Java, Indonesia.

\section{Conflicts of Interest}

The researchers state that there are no conflicts of interest in this study.

\section{References}

Allen, L. V. (2003). Contemporary Pharmaceutical Compounding. The Annals of Pharmacotherapy, 37(10), 1526. https://doi.org/10.1345/aph.1C508

Al-Nasser, A. N. (1991). Prescribing patterns in primary healthcare in Saudi Arabia. Dicp, 25(1), 90-93. https://doi.org/10.1177/106002809102500116

Brion, F., Nunn, A. J., \& Rieutord, A. (2003). Extemporaneous (magistral) preparation of oral medicines for children in European hospitals. Acta Paediatrica, 92(4), 486-490. https://doi.org/10.1111/j.1651-2227.2003.tb00583.x

Chareonkul, C., Khun, V. L., \& Boonshuyar, C. (2002). Rational drug use in Cambodia: study of three pilot health centers in Kampong Thom Province. Retrieved from https://www.ncbi.nlm.nih.gov/pubmed/12236445

Conroy, S., Choonara, I., Impicciatore, P., Mohn, A., Arnell, H., Rane, A., ... Raffaelli, M. P. (2000). Survey of unlicensed and off label drug use in paediatric wards in European countries. Bmj, 320(7227), 79-82. https://doi.org/10.1136/bmj.320.7227.79

Departemen Kesehatan Republik Indonesia [Depkes RI] (2007). The Guidelines for the Management of Public Drugs and Health Supplies in the Island regions. Retrieved from 
http://www.academia.edu/5159243/Pedoman_Pengelolaan_Obat_Publik_Dan_Perbekalan_Kesehatan_Di_ Daerah_Kepulauan

Di Paolo, E. R., Stoetter, H., Cotting, J., Frey, P., Gehri, M., Beck-Popovic, M., ... Pannatier, A. (2006). Unlicensed and off-label drug use in a Swiss paediatric university hospital. Swiss Medical Weekly, 136(13/14), 218.

Dos Santos, L., \& Heineck, I. (2012). Drug utilization study in pediatric prescriptions of a university hospital in southern brazil: off-label, unlicensed and high-alert medications. Farmacia Hospitalaria, 36(4), 180-186. https://doi.org/10.1016/j.farma.2010.12.008

Giam, J. A., \& McLachlan, A. J. (2008). Extemporaneous product use in paediatric patients: a systematic review. International Journal of Pharmacy Practice, 16(1), 3-10. https://doi.org/10.1211/ijpp.16.1.0002

Hapsari, I., Marchaban, M., Wiedyaningsih, C., \& Kristina, S. A. (2018). The Extemporaneous Compounding at Primary Health Care Centers: Characteristic and Personnel. Global Journal of Health Science, 10(9), 112. https://doi.org/10.5539/gjhs.v10n9p112

Kementerian Kesehatan Republik Indonesia [Kemenkes RI]. (2016). The Arrangement and Implementation Guidelines of National Formulary. Retrieved from http://farmalkes.kemkes.go.id/2016/01/pedoman-penyusunan-dan-penerapan-formularium-nasional/\#.W5n myeIxXDc

Kementerian Kesehatan Republik Indonesia [Kemenkes RI]. (2017). National Formulary. Retrieved from http://farmalkes.kemkes.go.id/2016/01/formularium-nasional/

Koper, D., Kamenski, G., Flamm, M., Bohmdorfer, B., \& Sonnichsen, A. (2013). Frequency of medication errors in primary care patients with polypharmacy. Family Practice, 30(3), 313-319. https://doi.org/10.1093/fampra/cms070

Kristina, S. A., Wiedyaningsih, C., Widyakusuma, N. N., \& Aditama, H. (2017). Extemporaneous Compounding Practice By Pharmacists: A Systematic Review. International Journal of Pharmacy and Pharmaceutical Sciences, 9(2), 42. https://doi.org/10.22159/ijpps.2017v9i2.15681

O'Brien, B. (1984). Patterns of European diagnoses and prescribing. Office of Health Economics. Retrieved from https://www.ohe.org/publications/patterns-european-diagnoses-and-prescribing

Otoom, S., Culligan, K., Al-Assoomi, B., \& Al-Ansari, T. (2010). Analysis of drug prescriptions in primary health care centers in Bahrain. Eastern Mediterranean Health Journal, 16(5), 511-515. https://doi.org/10.26719/2010.16.5.511

Pappas, A., MacPherson, R., \& Stewart, K. (2002). Extemporaneous prescribing: whatever happened to it? A survey of Australian general practitioners. Journal of Pharmacy Practice and Research, 32(4), 310-314. https://doi.org/10.1002/jppr2002324310

Rehan, H. S., \& Lal, P. (2002). Drug prescribing pattern of interns at a government healthcare centre in northern India. Tropical Doctor, 32(1), 4-7. https://doi.org/10.1177/004947550203200105

Saleh, K., \& Ibrahim, M. I. M. (2006). How rational are drugs used in Malaysian primary health care sector. Malays J Pharmaceut Sci, 4(1), 1-12.

't Jong, G., van der Linden, P., Bakker, E., van der Lely, N., Eland, I., Stricker, B., \& van den Anker, J. (2002). Unlicensed and off-label drug use in a paediatric ward of a general hospital in the Netherlands. European Journal of Clinical Pharmacology, 58(4), 293-297. https://doi.org/10.1007/s00228-002-0479-9

Thiers, B. H. (1998). Compounding is still appropriate in clinical practice. Dermatologic Clinics, 16(2), 329-330.https://doi.org/10.1016/S0733-8635(05)70015-2

Widyaswari, R., \& Wiedyaningsih, C. (2012). Evaluation of Compounding Prescription Profile And Availability of Medicine Pediatric Formulation In Primary Health Care Diy Province. Majalah Farmaseutik, 8(3), 227-234.

Wiedyaningsih, C., Hakimi, M., Soenarto, Y., \& Suryawat, S. (2016). The Use Of The Theory Of Planned Behavior To Predict Factors Influencing Physicians'decision To Prescribe Extemporaneous Compounding Dosage Form For Pediatric Outpatients. Asian Journal of Pharmaceutical and Clinical Research, 288-291.

World Health Organization [WHO]. (1993). How to Investigate Drug Use in Health Facilities. Retrieved from http://apps.who.int/medicinedocs/en/d/Js2289e/ 
World Health Organization [WHO]. (1996). Injection Practices in The Developing World: A Comparative Review of Field Studies in Uganda and Indonesia. Retrieved from http://www.who.int/iris/handle/10665/63371

World Health Organization [WHO]. (2011). WHO model list of essential medicines. Retrieved from http://www.who.int/medicines/publications/essentialmedicines/en/

\section{Copyrights}

Copyright for this article is retained by the author(s), with first publication rights granted to the journal.

This is an open-access article distributed under the terms and conditions of the Creative Commons Attribution license (http://creativecommons.org/licenses/by/4.0/). 